How to Cite

Suriani, N. L., \& Darmadi, A. A. K. (2019). Utilization of biotechnology staters to improve quality and production of clove plant (syzygium aromaticum 1). International Journal of Life Sciences \& Earth Sciences, 2(1), 38-43.

https://doi.org/10.31295/ijle.v2n1.92

\title{
Utilization of Biotechnology Staters to Improve Quality and Production of Clove Plant (Syzygium aromaticum L)
}

\author{
Ni Luh Suriani \\ Udayana University, Denpasar, Indonesia \\ Corresponding author email: niluhsurianisuriani@yahoo.com
}

\author{
Anak Agung Ketut Darmadi \\ Udayana University, Denpasar, Indonesia
}

\begin{abstract}
Clove plant is a commercial plant that has a lot of potentials. Gitgit Sukasada Village, Buleleng is one of the clove plantation centers, but lately, its production has decreased due to a large number of clove plants that have been attacked by the disease. For this reason, it is necessary to research how to increase production. The purpose of this research is to get organic fertilizer products that are environmentally friendly that can improve the quality and production of clove plants. The design used is a randomized group design. The results showed that biostaters could accelerate the maturity of organic fertilizer, within 30 days organic fertilizer was ready to be used and the quality of the fertilizer could be improved. The results of research on clove plants at the age of 20 years showed that the treatment of organic fertilizer 2 tons/ ha and 3 tons/ha had a significant effect on the number of flowers /stems and dry weight /trees, and so were not found sick plants. Whereas in the control and treatment of 1 ton /ha organic fertilizer, sick clove plants were found. Adapted compost fertilizer also increases the brightness of the leaf's color, and can increase the size of the clove fruit.

Keywords---biostater, clove, organic fertilizer.
\end{abstract}

\section{Introduction}

Clove plants in Indonesia are considered plantations, besides cocoa, coffee and rubber. Clove plants to be able to grow and produce require specific growing environmental requirements. Environmental factors that influence clove plants include climate, height, and type of soil. Optimal rainfall for the development of clove plants is 1,500 - 2,500 $\mathrm{mm} /$ year or $2,500-3,500 \mathrm{~mm} /$ year with a dry month of fewer than 2 months. The intensity of irradiation is $61-60 \%$ and the temperature is $22-28^{\circ} \mathrm{C}$ and there are no strong winds throughout the year. Clove plants can be planted and still produce at an altitude of 0 - $900 \mathrm{~m}$ above sea level (asl) (Ireng, 2017; Yadnya et al., 2016; Partama et al., 2018).

Clove is a commodity for domestic and export. In Bali, many spas use clove oil as therapeutic aroma oil, which is very liked by guests. Besides that, the clove plant is one of the natural attractions which is liked by the guests. In the world of agriculture, cloves are widely used as plant-based pesticides. Clove plants are also used as herbs for spices (Ristiansyah et al., 2018). In Bali, one of the centers of clove plants is in the district of Buleleng, namely in the village of Gitgit, sub-district of Sukasada. From the survey results found that the development of cloves there is quite good but there are deficiencies in treatment. Especially the fertility of the soil begins to decline so that many clove plants that die due to pests and diseases and thin clove plants and yellow leaves tend to turn yellow. From the results of interviews that clove farmers in the village tended from year to year to always use synthetic fertilizers. The impact arising in long-term use is a decrease in soil fertility, pests and disease increases (Hartatik \& Widowati, 2015). So that gradually the production decreases, the welfare of farmers decreases.

This village is also a center of rice farming and each resident owns cattle and pigs. Rice waste in the form of abundant straw, mostly processed by burning. Likewise, there is an abundance of livestock waste without treatment that spreads foul odors that pollute the environment. If this is used and treated as organic fertilizer, farmers will not 
lack fertilizer, besides that the costs are also low, welfare will increase. But because the knowledge/technology about it is not so well known by farmers, farmers have objections in buying fertilizer. As a result, the production of cloves is not optimal. The purpose of this research is to get organic fertilizer products that are environmentally friendly and improve the quality and production of clove plants through the application of compost organic fertilizer on clove plants.

\section{Research Methods}

The research is in the village Amertasari, Sukasada Buleleng. This research is field research consisting of 2 stages, stage I making organic fertilizer using biostater (Trichoderma sp, and Aspergillus niger). Phase II is the application of organic fertilizer to clove plants by the randomized block design method, with 4 treatments and 4 replications. These treatments are treatment without fertilizer (F0), treatment with organic fertilizer 1 ton/ha (F1), treatment with organic fertilizer 2 tons/ha (F2), treatment of organic fertilizer 3 tons/ha (F3). The parameters observed were fertilizer quality parameters (odor, color, and appearance of fertilizer) and production parameters and clove quality (leaf color, flower length and width, number of flowers/stems, flower color and flower/tree weight). Data analysis used quantitative analysis using analysis of variance (ANOVA), if the treatments were significantly different, followed by the multiple range test (DMRT) at the 5\% level (Gomez, 2007; Yuliara et al., 2018; Zambrano et al., 2019).

\section{Results and Discussion}

\section{Quality of Compost Fertilizer}

The quality of organic fertilizer is presented in Table 1. Inorganic fertilizers with biostater, it shows that the texture is a crumb, odorless, ripe and brownish in color. Whereas organic fertilizer without biostater shows a rather dense texture, smelly, undercooked and brownish color. Antonious (1997), states that biostater is a microbe that functions to accelerate the process of degradation, can suppress pathogenic microbes and stimulate the growth of decomposing microbes. This can accelerate the maturity of organic fertilizer. Suriani et al., (2015), states that biostater can accelerate the maturity of organic fertilizer, within 30 days organic fertilizer is ready to use. Organisms found in biostater such as Aspergillus niger and Trichoderma sp. Trichoderma organism is a remodel organism and can also suppress plant pathogens, function as biocontrol and can increase plant growth and production. Trichoderma $s p$ can also suppress blast disease in rice plants (Gomathinayagam et al., 2009; Kumar et al., 2017; Yaday et al., 2018; Eiham et al., 2012; Yutida et al., 2014; Ram \& Norman, 2018; Zee \& Vu, 2018).

Table 1

Compost quality organic fertilizers at each treatment

\begin{tabular}{|c|c|c|c|}
\hline No. & Parameters & $\begin{array}{l}\text { Organic fertilizer } \\
\text { without biostater }\end{array}$ & $\begin{array}{l}\text { Organic fertilizer with } \\
\text { biostater }\end{array}$ \\
\hline F0 & Smell & Smelling pungent & - \\
\hline F1 & Color & Brownish black & Brownish black \\
\hline $\mathrm{F} 2$ & Texture & Solid crumbs & crumbs \\
\hline F3 & Maturity & Less mature & Maturity \\
\hline
\end{tabular}

\section{Production}

Results of research on clove plants aged 20 years (Figure 3) showed that the treatment of organic fertilizer 2 tons/ ha and 3 tons/ ha significantly affected the number of flowers/stems and the dry weight of flowers/trees (Figure 2; tables 2 , 2) Figure 2 shows the higher concentration of organic fertilizer, the number of flowers and flower weight increases. No diseased plants were found in the treatment F2 and F4, while in control and F1 found. In the control and treatment of organic fertilizer 1 ton/ha found a clove plant that is sick with the characteristics of leaves and branches to dry out gradually. 
Table 2

Number of clove plant flowers

\begin{tabular}{llllll}
\hline Treatment & \multicolumn{5}{c}{ Number of clove plant flowers/stalk } \\
\cline { 2 - 6 } & 1 & 2 & 3 & 4 & Everage \\
\hline & 17 & 18 & 16 & 16 & $16.75 \mathrm{a}^{*}$ \\
F0 & 18 & 17 & 18 & 17 & $17.50 \mathrm{~b}$ \\
F1 & 19 & 18 & 18 & 19 & $18.50 \mathrm{c}$ \\
F2 & 19 & 19 & 18 & 19 & $18.75 \mathrm{c}$ \\
F3 & 19
\end{tabular}

Table 3

Weight of dried flowers per tree

\begin{tabular}{llllll}
\hline \multirow{2}{*}{ Treatment } & \multicolumn{5}{c}{ Weight of dried flowers per tree } \\
& \multicolumn{5}{c}{ Replication } \\
\cline { 2 - 6 } & 1 & 2 & 3 & 4 & Everage \\
F0 & 6.0 & 5.90 & 6.10 & 6.21 & $6.10 \mathrm{a}^{*}$ \\
F1 & 6.25 & 6.10 & 6.05 & 6.30 & $6.18 \mathrm{a}$ \\
F2 & 7.0 & 7.0 & 7.10 & 7.0 & $7.03 \mathrm{~b}$ \\
F3 & 7.9 & 7.9 & 7.70 & 7.70 & $7.80 \mathrm{~b}$ \\
\hline
\end{tabular}

The use of synthetic fertilizers and pesticides continuously can damage the land, many decomposing microbes in the soil die so that the availability of nutrients is reduced. Hartatik \& Widowati (2015), states that organic fertilizers contain microbes that can suppress pathogenic microbes in the soil so that plants avoid disease. Suriani et al., (2019), that organic fertilizer with biostater can increase the yield of Bali local dry rice. Likewise, the results of Santi (2006), show that compost fertilizer has a significant effect on tomato plant height. The number of cabbage leaves increased due to the use of liquid organic fertilizer R11 at a concentration of $2 \mathrm{ml} / 0.5 \mathrm{~L} . \%$ (Nandissa et al., 2012). The content of nutrients $\mathrm{P}$ and $\mathrm{K}$ in organic fertilizer stimulates flowering (Hartatik \& Widowati, 2015). Anthurium flowers are brighter in color after the application of organic fertilizer with starter biotechnology (Suriani et al., 2016). Compost also has a significant effect on the growth of ornamental plants and can function as bioremediation (Parwanayoni et al., 2015). Various types of organic fertilizer tried on clove plants can increase the diameter of clove plants by $29.9 \%$ for 12 weeks (Ratih \& Ade, 2015). Clove crop production is strongly influenced by several factors including how to cultivate such as fertilization (Ireng, 2017). Yudi \& Ridwan (2016), that organic fertilizer responds to increasing clove plant height and increasing soil moisture.

Organic fertilizers are also effective in increasing $\mathrm{P}$ uptake and increasing soybean yields (Supriyadi et al., 2016). Organic fertilizer combined with $30 \%$ compost can increase the yield of red Balinese rice (Suriani et al., 2019).

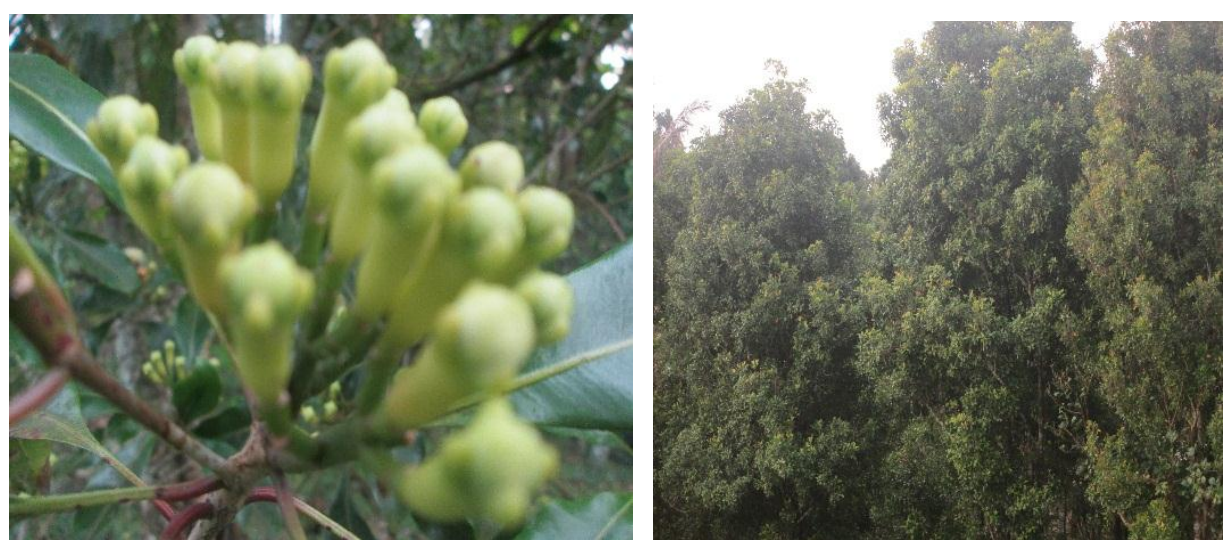

Figure 1. Clove plant 


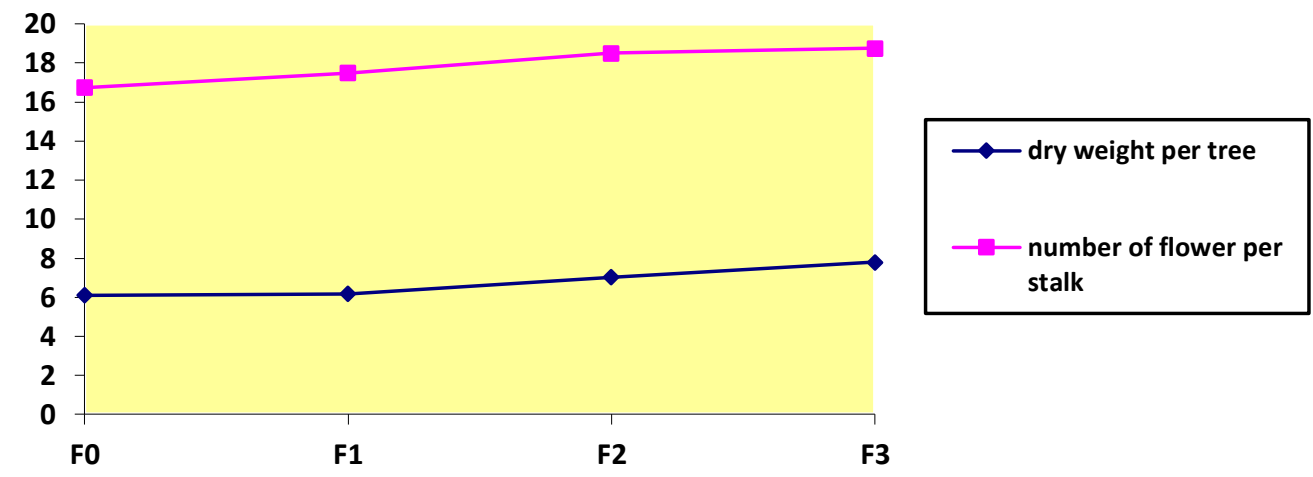

Figure 2. Clove production

\section{Quality of Clove Flowers}

Table 4 shows the colors in different treatments and controls, the green leaf control while the shiny green treatments. The application of compost organic fertilizer also significantly affected the treatment $(\mathrm{P}<0.05)$. The higher the compost concentration, the higher the flower length and width. High nutrient $\mathrm{P}$ and $\mathrm{k}$ nutrients in the media affect the flowering of a plant. Suriani et al., (2019), that the use of nutrients can increase the size of hortensia flower diameter, and can brighten the color of the flower. Figure 3 shows the higher the compost concentration, the greater the flower size. Nutrients contained in compost are sources of nutrients for plants and can increase production.

Table 4

The Quality of clove

\begin{tabular}{llll}
\hline Treatment & Color of leaf & $\begin{array}{l}\text { Flower length } \\
(\mathrm{cm})\end{array}$ & $\begin{array}{l}\text { Flower width } \\
(\mathrm{cm})\end{array}$ \\
\hline F0 & Green & $1.5 \mathrm{a}^{*}$ & $0.7 \mathrm{a}^{*}$ \\
F1 & Shiny green & $1.55 \mathrm{a}$ & $0.72 \mathrm{a}$ \\
F2 & Shiny green & $1.7 \mathrm{~b}$ & $0.79 \mathrm{~b}$ \\
F3 & Shiny green & $1.99 \mathrm{c}$ & $0.80 \mathrm{~b}$ \\
\hline
\end{tabular}

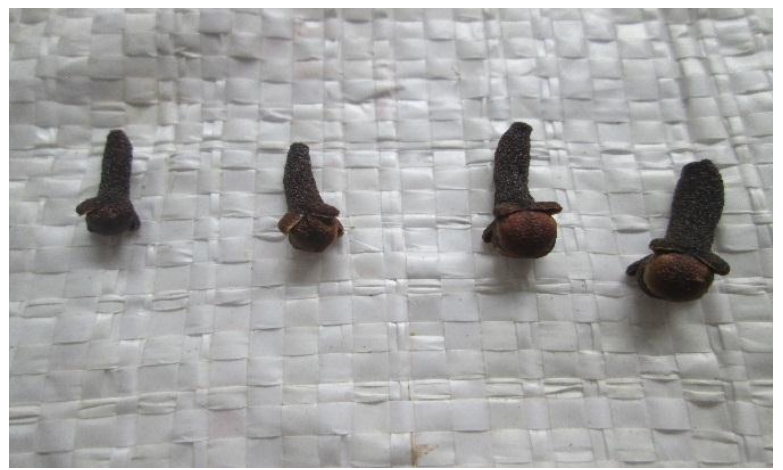

Figure 3. Dry clove flowers from left to right F0, F1, F2, F4 


\section{Conclusion}

The conclusion of this research is the biotechnology of the starter added when making organic fertilizer can improve the quality of fertilizers such as odor and texture to be better. Application of organic fertilizer to clove plants can improve the quality and production of cloves.

\section{Acknowledgments}

Thank you to LPPM UNUD and DIKTI as funders, and we thank the clove farmer group of Gitgit Village for providing land/gardens for the ongoing research.

\section{References}

Antonious, A. J. (1997). U.S. Patent No. 5,658,206. Washington, DC: U.S. Patent and Trademark Office.

Darwati, I. (2018). Penekanan fluktuasi produksi cengkeh (Syzygium aromaticum) dengan mekanisme fisiologi/suppression of fluctuations Clove (Syzygium aromaticum) Production With Fisiology Mecanism. Perspektif, 16(2), 93-101.

Eiham .K., M. Sadravi, S. Naelmi, \& V. Khosravi. (2012). Bioogical Control of Rice Brown Sport with Native Isolates of Three Trichoderma species. Braziian Journal of Microbioogy, 297-305.

Gomathinayagam, S., Rekha, M., Murugan, S. S., \& Jagessar, R. C. (2009). Biological Control Of Rice Disease (Blast) By Using Trichoderma Viride In Laboratory Conditions (No. 1876-2017-264).

Gomeis, L., Rehatta, H., \& Nandissa, J. (2012). Pengaruh Pupuk Organik Cair RI1 Terhadap Pertumbuhan Dan Produksi Tanaman Kubis Bunga (Brassisca Oleracea var. botrytis L.). Fakultas Pertanian Universitas Pattimura.

Gómez, M. J., Bueno, M. M., Lacorte, S., Fernández-Alba, A. R., \& Agüera, A. (2007). Pilot survey monitoring pharmaceuticals and related compounds in a sewage treatment plant located on the Mediterranean coast. Chemosphere, 66(6), 993-1002. https://doi.org/10.1016/j.chemosphere.2006.07.051

Hartatik, W., \& Widowati, L. R. (2015). Pupuk kandang,[29 april Tanaman Padi (Oryza sativa. L) Akibat Pengaruh Persentase N (Azolla dan urea). Makalah Seminar Departemen Agronomi dan Hortikultura IPB. Hal.

Hidayat, Y. S., \& Nurdin, M. (2014). Penggunaan Trichoderma sp. sebagai agensia pengendalian terhadap Pyricularia oryzae Cav. penyebab blas pada padi. Jurnal Agrotek Tropika, 2(3).

Khadka, R. B., \& Uphoff, N. (2019). Effects of Trichoderma seedling treatment with System of Rice Intensification management and with conventional management of transplanted rice. PeerJ, 7, e5877.

Kumar, S., Lal, A. A., Kumar, N., Jaiswal, S., Kumar, H., Kumar, A., \& Kumar, M. (2017). Effect of bio control agents and botanicals against Blast of Paddy caused by Pyricularia oryzae. International Journal of Chemical Studies, 5(1), 314-318.

Partama, I. B., Yadnya, T. G., Trisnadewi, A. A. A. S., \& Sukada, I. K. (2018). Fermented rice husk utilization of effective microorganisms-4 supplemented with Piper betle L. performance, meat quality, antioxidant capacity, and meat cholesterol levels of Bali duck. International Journal of Life Sciences, 2(3), 98-110. https://doi.org/10.29332/ijls.v2n3.215

Ratih, S. \& Ade, W. (2015). Pertumbuhan tanaman cengkeih (Syzygium aromaticum L) Belum menghasilkan pada Berbagai Dosis Pupuk Organik dan Intensitas Naungan. Bul. Agrohorti, 3(1), 87-94.

Ristiansyah, D. U., Yenita, Y., Melviana, M., \& Annisa, A. (2018). Uji efektivitas antibiotik ekstrak daun cengkeh (syzygium aromaticum) terhadap pertumbuhan bakteri salmonella typi secara in vitro. Jurnal ibnu sina biomedika, 2(1), 41-47.

Santi, D. V., McHenry, C. S., \& Sommer, H. (1974). Mechanism of interaction of thymidylate synthetase with 5fluorodeoxyuridylate. Biochemistry, 13(3), 471-481.

Supriyadi, B., \& Mungkasi, S. (2016). Finite volume numerical solvers for non-linear elasticity in heterogeneous media. International Journal for Multiscale Computational Engineering, 14(5).

Suriani, N. L., Darmadi, A. A. K., Parwanayoni, N. M. S., Hamid, M. H. N. A., \& Yamin, B. M. (2019). The combination of piper Caninum Blume leaf extract and compost fertilizer for pressing blast disease and improving growth of bali red rice (Oryza Sativa Linn). International Journal on Advanced Science, Engineering and Information Technology, 9(2), 518-525.

Suriani, N. L., Parwanayoni, N. M. S., \& Suartini, N. M. (2015). Meningkatkan Produksi Bunga Potong Anthurium SP Melalui Pemanfaatan Pupuk Organik. Buletin Udayana Mengabdi, 15(2), 19-23.

Suriani, N. L., Parwanayoni, N. M. S., \& Suartini, N. M. (2015). Meningkatkan Produksi Bunga Potong Anthurium Sp Melalui Pemanfaatan Pupuk Organik. Buletin Udayana Mengabdi, 15(2), 19-23. 
Yaday, J. S., \& Yaday, A. S. (1987). Localization of NORs in spermatogonial metaphase chromosomes of six species of grasshoppers. Genetica, 74(2), 155-160.

Yadnya, T. G. B., Trisnadewi, A. A. A. S., Sukada, I. K., \& Oka, I. G. L. (2016). The effect of offered diet containing rice hull and mono sodium glutamate $(\mathrm{msg})$ and effective microorganism $-4(\mathrm{em}-4)$ solution on the performance of campbell duck. International Research Journal of Engineering, IT \& Scientific Research, 2(11), $75-82$.

Yan, Z. K., \& Anh, V. T. T. (2018). Effect of Trichoderma sp. on Anthracnose Disease of Stored Chilli. Borneo Journal of Resource Science and Technology, 8(2), 90-102. https://doi.org/10.33736/bjrst.1211.2018

Yuliara, I. M., Sutapa, G. N., \& Kasmawan, G. A. (2018). Development and optimization of the ratio vegetation index on the visible and infrared spectrum. International Journal of Physical Sciences and Engineering, 2(2), 101-110. https://doi.org/10.29332/ijpse.v2n2.172

Yusdian, Y., \& Haris, R. (2017). Respon Pertumbuhan Bibit Cengkeh (Syzgium aromaticum (L.) Merr dan Perry) kultivar zanzibar akibat pupuk npk dan pupuk organik cair. Paspalum: Jurnal Ilmiah Pertanian, 4(1), 59-65.

Zambrano, T. Y. M., Castro, I. C. G., Plaza, C. L. M., \& Farfan, R. M. (2019). Recovery of ancestral knowledge for production of traditional Manabí cocoa paste. International Journal of Life Sciences, 3(1), 71-78. https://doi.org/10.29332/ijls.v3n1.274 